\title{
Is Citizenship an Effective Solution to the Palestinian Refugee Plight?
}

\author{
RADHIKA CHAUDHRI
}

\section{Abstract}

While a lasting solution to the Israeli-Palestinian conflict remains elusive, Palestinian refugees displaced during the formation of Israel face an uncertain future. More than four million Palestinians live as refugees in neighboring Middle Eastern states, often in marginalized circumstances. It is in this context that citizenship has been suggested by some commentators as a means of providing them with formal status and therefore a basis upon which rights may be protected. Focusing on Lebanon, this paper examines the potential of citizenship as a solution to the systemic deprivation suffered by this population. Ultimately, any proposed solution has no salience beyond the rights it can secure. In examining the geo-political realities of this volatile region, the author suggests that citizenship, in any of its current potential manifestations, is an undesirable and ultimately ineffective solution to the Palestinian refugee problem.

Displaced Palestinians represent the longest enduring unresolved refugee problem in the world, ${ }^{1}$ and a failure of the international community to achieve a durable solution to the Israeli-Palestinian conflict. Sixty years after the formation of Israel and ensuing Palestinian exodus, more than four million Palestinians remain living as refugees in neighbouring Arab countries with "almost a total absence of guarantees for basic rights." ${ }^{2}$ Lack of formal status has often resulted in compromised provision of services and protection for these refugees, and their continual marginalisation has prompted many international leaders

\footnotetext{
1 Donna Arzt, Refugees Into Citizens: Palestinians and the End of the Arab-Israeli Conflict, (New York: Council on Foreign Relations, 1997), 120.

2 Asem Khalil, "Palestinian Nationality and Citizenship: Current Challenges and Future Perspectives", Euro-Mediterranean Consortium for Applied Research on International Migration, Research Report 2007-07, European University Institute, 2007, 29.
} 
and commentators to call for the repatriation or resettlement of Palestinians currently living in camps. The question of whether Palestinians need to belong to a secure nation-state has presented significant challenges for policy-makers, as it can be considered from many different perspectives and opens complex discourse regarding the concepts of 'nation' and 'belonging' that cannot be fully addressed here. This essay will focus instead on Lebanon, since this "may be the most inhospitable country of refuge for Palestinians," ${ }^{\prime 3}$ and consider whether citizenship is 'needed' to ensure basic rights for them. Ultimately, none of the current citizenship options available to this Palestinian diaspora amounts to a substantive solution for these refugees. While providing each refugee with a holistic membership to a secure nation-state is a relatively uncontroversial ideal position, the Lebanese context demonstrates the dangers of transposing this normative framework onto the volatile political reality of the Middle East.

Palestinians who fled to neighbouring Lebanon are "the most destitute grouping of Palestinian refugees in any Arab host country," ${ }^{4}$ and therefore provide an instructive context for examining the debate over citizenship. Lebanon is home to four hundred thousand refugees, who comprise about one tenth of its population. ${ }^{5}$ Although many of these refugees entered the country more than half a century ago, most still reside in camps and "sixty percent of the Palestinians in Lebanon live below the poverty line." ${ }^{\prime 6}$ Not only have they been persistently denied naturalisation as Lebanese citizens, but "the Lebanese government has made every effort to make life uncomfortable, and Lebanon unwelcoming, for the Palestinian community." 7 This hostility should be understood in conjunction with the religious composition of Lebanon, which has substantial Christian Maronite and Shi'a populations. The predominantly Sunni Palestinian refugees are therefore considered a destabilising threat to this delicate sectarian balance. ${ }^{8}$ This is demonstrated most clearly in the legal classification of Palestinians as foreigners, ${ }^{9}$ which operates with the reciprocity doctrine, enshrined in Lebanese law, to deprive Palestinians. The reciprocity doctrine provides employment and other entitlements to foreigners in Lebanon in reciprocal measure to the entitlements that Lebanese nationals would receive in the foreigner's country of origin. As Palestinian refugees are stateless and therefore cannot claim 'most

\footnotetext{
3 Susan Akram and Guy Goodwin-Gill, "Brief Amicus Curiae: The Status of Palestinian Refugees Under International Refugee Law", to the United States Department of Justice, Executive Office of Immigration, United States Board of Immigration Appeals, 2000, 26.

4 Jaber Suleiman, "Refugees or Foreigners? The Case of Palestinians in Lebanon" in Grabska, K and Mehta, L (eds), Forced Displacement: Why Rights Matter, (London: Palgrave Macmillan, 2008), 93-164, 94.

5 Rex Brynen, "Imagining a Solution: Final Status Arrangements and Palestinian Refugees in Lebanon," Journal of Palestine Studies, 26:2, (Winter 1997), 42-58, 53.

6 Arzt, Refugees Into Citizens, 46.

7 Brynen, "Imagining a Solution" 48.

8 International Crisis Group, "Palestinian Refugees and the Politics of Peacemaking", ICG Middle East Report No 22, 5 February 2004, 14.

9 Suleiman, "Refugees or Foreigners?", 95.
} 
favoured nation' status, the reciprocity doctrine deliberately operates in labour, association, social security and property ownership laws to effectively "single out the stateless Palestinian refugees for exclusion." 10

Not only are Palestinian refugees in Lebanon systematically discriminated against at general law, but have also been periodically "killed, imprisoned, tortured, and expelled,"11 usually in the context of regional geopolitical conflict. Armed exchanges between the Palestinian Liberation Organisation and the Israelis were widely regarded by the Lebanese as exposing Lebanon to the hostilities of the Israeli-Palestinian conflict, and therefore the Lebanese government has increasingly sought to deprive Palestinians of as much agency as possible. Intensifying Israeli strikes on Lebanese camps from 1982 fuelled a Civil War in which refugee camps were attacked, ${ }^{12}$ most notably in the refugee camps of Sabra and Shatila, where the Christian Phalange launched "a massacre of the civilian population." 13 After more than a decade of attacks and raids, the Taif Accord released by the Lebanese government in 1989 marked the end of the Civil War and explicitly excluded the possibility naturalising Palestinian refugees, ${ }^{14}$ leaving them to remain as "stateless persons living in perpetual limbo." 15 In 2009, Lebanese officials continue to express intentions to expel all Palestinians at the earliest possible opportunity. ${ }^{16}$

Palestinian deprivation and persecution stems "in part from their lack of standing as subjects of international law." ${ }^{\prime 17}$ This has led commentators such as Arzt to propose citizenship as the only robust means of "cementing... civil, political and especially social rights." ${ }^{18}$ As the "world's largest concentration of stateless persons," ${ }^{19}$ Palestinians occupy a "legal vacuum," ${ }^{20}$ and are unable to claim legal personality and the entitlements that would flow from this. While statelessness precludes a person from invoking diplomatic protection, Arzt and others claim that, "through citizenship, individuals demarcate their legal status, and become citizens as opposed to foreigners." ${ }^{21}$ While Arzt understands citizenship as a substantive concept beyond a formal legal classification, allowing Palestinians

\footnotetext{
10 Khalil, "Palestinian Nationality and Citizenship", 31.

11 Akram and Goodwin-Gill, "Brief Amicus Curiae: The Status of Palestinian Refugees Under International Refugee Law", 28.

12 Helena Lindholm Schulz, The Palestinian Diaspora: Formation of Identities and Politics of Homeland, (London: Routledge, 2003), 56.

13 Jean Allain, International Law in the Middle East: Closer to Power than Justice, (Aldershot: Ashgate, 2004), 111-112.

14 Suleiman, "Refugees or Foreigners?", 97.

15 Allain, International Law in the Middle East, 101.

16 Arzt, Refugees Into Citizens, 47.

17 Allain, International Law in the Middle East, 114.

18 Arzt, Refugees Into Citizens, 3.

19 Ibid, 74.

20 Jean Allain, International Law in the Middle East: Closer to Power than Justice, (Aldershot: Ashgate, 2004), 125.

21 Khalil, "Palestinian Nationality and Citizenship", 40.
} 
to "truly exercise choice and to affect the course of their own lives,"22 other commentators such as Allain regard any formal legal status as a viable foundation for the provision of rights. Under either conception, citizenship is seen as the key to guaranteeing human rights for Palestinian refugees, "giving [them] the voice they have been denied for over three generations." ${ }^{23}$

However, few share Arzt's optimism about the potential for a final status solution, citing the volatile geopolitical situation of the Middle East as effectively precluding any realistic prospect of citizenship for Palestinian refugees. For refugees in Lebanon, the citizenship possibilities open to them are: resettlement as Lebanese citizens, a return to their original homeland now in Israel, or repatriation to a new Palestinian state. It is relatively clear that the Palestinian refugees in Lebanon cannot expect to resettle there as citizens. Since their arrival they have been consistently "regarded as a security problem," 24 and three quarters of Lebanese oppose Palestinian resettlement. ${ }^{25}$ The Lebanese fear that "implantation will tip the political balance of religious and ethnic groups in the country" 26 has now concretised itself in national law. After the Taif Accord, which states, "there shall be no settlement of Palestinians in Lebanon" 27 and subsequent Constitutional amendment, the possibility of resettling Palestinians as citizens has been categorically rejected by the Lebanese people. For their part, "there are few Palestinians who would like to stay there permanently, even if given citizenship." ${ }^{28}$ Anti-Palestinian sentiment in Lebanon highlights the Palestinian fear that integrating into the Lebanese population would not provide any meaningful guarantee of rights, while at the same time extinguishing their right of return and claims to compensation. ${ }^{29}$ Thus, acquiring Lebanese citizenship appears an unlikely and ultimately ineffective answer for securing refugee rights.

Similarly, a hostile Israeli government makes return to Israel both unrealistic and undesirable for Palestinians. For most refugee populations, an alternative to permanent settlement in a country of refuge is a return to country of origin. Once returned, refugee status ceases as the persons concerned become subjects of the state as citizens. In this regard, Palestinians occupy the unusual position of being indefinitely prevented from returning to their homes by virtue of the sovereign exercise of migration control by the Israeli government. Although

\footnotetext{
22 Arzt, Refugees Into Citizens, 120.

23 Ibid, 116.

24 Khalil, "Palestinian Nationality and Citizenship", 31.

25 Rex Brynen, "Imagining a Solution: Final Status Arrangements and Palestinian Refugees in Lebanon," Journal of Palestine Studies, 26:2, (Winter 1997), 42-58, 53

26 Khalil, "Palestinian Nationality and Citizenship", 31.

27 Suleiman, "Refugees or Foreigners?", 97.

28 Arzt, Refugees Into Citizens, 47.

29 Ilan Peleg, "The Palestinian Refugees: A Political Perspective" in Ferris, Elizabeth (ed), Refugees and World Politics, (New York: Praeger, 1985), 152-167, 158.
} 
"most Palestinian official discourse on the right of return lacks nuance..." 30 , its classical formulation is by reference to the 1948 United Nations General Assembly Resolution 194(III), which provides: "refugees wishing to return to their homes and live at peace with their neighbours should be permitted to do so at the earliest practicable date." However, as early as 16 June 1948, the Israeli Prime Minister Ben-Gurion decided that Palestinians were not allowed to be allowed to return. ${ }^{31}$ Successive Israeli governments have cited "Israel's 'demographic security' as the consequent need to prevent a situation where the Palestinian Authority floods Judea and Samaria with returning refugees." ${ }^{32}$ In any case, for the Palestinians, returning to their 'homeland' as Israeli citizens is unlikely to be acceptable or considered to be genuine return. In addition, the ongoing Israeli-Palestinian conflict and mutual accusations of terror and violence strongly suggest that acquiring Israeli citizenship may create legal personality for the refugees, but would not provide them with 'membership' to the nation of Israel such that they could be guaranteed the enjoyment of rights and freedoms. In any case, the official Israeli position makes it clear that refugee return "will not, under any conceivable circumstances be realised." ${ }^{33}$

With both resettlement in Lebanon and return to Israel effectively ruled out by the respective governments, the final citizenship option for Palestinians in Lebanon is repatriation to a new Palestinian state. While a solution of this kind "is more attractive for host neighbour states that refuse to naturalise Palestinian refugees," 34 its most obvious deficiency is the current absence of any such Palestinian nation. The conferral of Palestinian citizenship requires the establishment of a Palestinian state, which in turn is dependant on a durable peace settlement with Israel, and thus "the refugee problem is ultimately inseparable from the underlying cause of the decades-long conflict." ${ }^{35}$ The essential condition of a negotiated two-state solution has proven extremely elusive in the sixty years since the creation of Israel. After several major wars, three intifadas and continual cross border attacks, most recent polling from June 2009 reveals that sixty-seven percent of the Palestinians and sixty-two percent of the Israelis believe that it is completely impossible to reach a final status agreement. ${ }^{36}$ Thus it seems unlikely that the Palestinians in Lebanon will

\footnotetext{
30 Brynen, "Imagining a Solution", 45.

31 Jean Allain, International Law in the Middle East, 106.

32 Brynen, "Imagining a Solution", 46.

33 Ibid, 45.

34 Khalil, "Palestinian Nationality and Citizenship", 38.

35 Arzt, Refugees Into Citizens, 83.

36 Palestinian Centre for Policy and Survey Research, “PRESS RELEASE: Joint Israeli-Palestinian Poll, June 2009: Pessimism among Israelis and Palestinians regarding the prospects for a settlement and a Palestinian state in the next few years, but majorities on both sides support a two-state solution." <http://www.pcpsr. org/survey/polls/2009/p32ejoint.html> (June 14, 2009) accessed 19 September, 2009.
} 
be able to claim citizenship to a new Palestinian state, the formation of which depends on a peace agreement that has so far eluded every government that has pursued it.

Further complications arise as to what level of control the Israeli government might retain over Palestine if borders for the two states could be settled. In assessing the efficacy of citizenship in ensuring rights for Palestinian refugees, this issue is particularly significant. At present, Israeli forces have imposed tight border controls and blockades restricting the supply of food and access to land in both Gaza and the West Bank. These blockades have been described by international commentators as a "policy of collective punishment... to punish Gazans for political developments within the Gaza strip, constituting a continuing flagrant and massive violation of international humanitarian law." ${ }^{37}$ The resulting strain on the Palestinian territories has resulted in eighty percent of Gazans living below the poverty line, and blocks on exports have effectively frozen business activity. ${ }^{38}$ Thus, if citizenship is pursued as a tool for securing basic rights for refugees, the current situation provides little surety of any such guarantee. Membership to a Palestinian state is only a substantive solution for refugees in Lebanon if the Palestinian state they are absorbed into differs substantially in its relations with Israel and commands sovereign authority over its territory, both of which are far from assured.

Even if these obstacles could be overcome, further problems prevent Palestinian refugees from full enjoyment of membership to a new Palestine. Firstly, "international experience suggests in general that the number of refugees who choose homeland repatriation is often much smaller than planners and activists initially anticipate." 39 This phenomenon seems likely in Lebanon, where "less than one percent have family connections in the West Bank or Gaza." ${ }^{40}$ Of the four hundred thousand refugees, only "approximately three percent of the Palestinians in Lebanon were born in Palestine before 1948. As the conflict continues without resolution, this number is likely to shrink." ${ }^{41}$ This means that for many, the new Palestine would be another foreign state with which they have no personal connection, and makes resettlement there an unattractive prospect unlikely to confer a sense of membership. In addition, "many Palestinians in Lebanon could not afford to relocate to the West Bank or Gaza,"42 rendering useless any de jure entitlement to citizenship they might have. This point is particularly significant in the event that the creation of a Palestinian state triggers

37 United Nations, 'Gaza: Silence is not an option - The Special Rapporteur on the situation of human rights on Palestinian territories occupied since 1967, Richard Falk, issued the following statement' (Press Release, 9 December 2008).

38 UK Home Office, Operational Guidance Note on Israel, Gaza and the West Bank, February 2009, para 3.6.5.

39 Brynen, "Imagining a Solution", 48.

40 Ibid.

41 Ibid.

42 Ibid. 
the Lebanese government to "place additional pressures on refugees to leave." ${ }^{43}$ If the Lebanese government introduced further restrictions on Palestinians in an effort to expedite their transfer to Palestine, this would be counterproductive for the refugees in question. The practical effect would be to trap those too poor to move from Lebanon with even fewer rights than they can currently claim. ${ }^{44}$ Thus, even if all barriers to the creation of a functional Palestinian state could be overcome, offering refugees repatriation remains a path fraught with difficulties and the insidious potential to promote intensified oppression by the Lebanese government.

It is therefore critically important not to view membership to a particular state as a solution unto itself, particularly in the context of Palestinian refugees. Rather, the merit of citizenship lies in its effectiveness as a means toward the ultimate goal of providing a durable guarantee of basic rights and security. While citizenship is one means of accessing such protection, international law regimes and diplomatic negotiation also provide mechanisms for obtaining these basic conditions. ${ }^{45}$ Significantly, the pursuit of international protection schemes and international diplomatic intervention require Palestinians to maintain their refugee status. Since "new Palestinian refugees [were] barred from returning to their homes, and also were retroactively deprived of their citizenship," ${ }^{46}$ their refugee status embodies their marginality, and hence keeps the unresolved Palestinian problem highly visible in the international community. Indeed, "most of the refugees themselves wished to become neither Israeli citizens nor citizens of their host countries since either would acquiesce in the legitimacy of the state of Israel." 47

It is estimated that of 6, 375, 800 Palestinian refugees, only 2, 643, 764 have been granted citizenship anywhere in the world. ${ }^{48}$ For those who have been unable or unwilling to accept some form of citizenship, the status of 'refugee' is perceived as an asset in the battle to survive, and a latent form of power. ${ }^{49}$ Thus, contrary to the claims of Arzt and other proponents of a state-based solution, "refugee activism is the ideal instrument" have described as "the dream of two-thirds of the Palestinian people;" genuine recompense for Palestinian refugees. In this sense, "Palestinians' rights

\footnotetext{
43 Rex Brynen, “Refugees, Repatriation and Development: Some Lessons from Recent Work," (Paper presented at the Stocktaking Conference on Palestinian Refugee Research, Ottawa, June 17-20 2003), 3.

44 Ibid.

45 Lex Takkenburg, The Status of Palestinian Refugees in International Law, (Oxford: Clarendon Press, 1998).

46 Akram and Goodwin-Gill, "Brief Amicus Curiae", 20-21

47 Ibid, 25.

48 Ibid, 24.

49 Suleiman, "Refugees or Foreigners?", 95.

50 International Crisis Group, "Palestinian Refugees and the Politics of Peacemaking", ICG Middle East Report No 22, 5 February 2004, 7.

51 International Crisis Group, "Palestinian Refugees and the Politics of Peacemaking", ICG Middle East Report No 22, 5 February 2004, 9.
} 
as individuals are sacrificed for the sake of 'Palestinian national interest." 52 Ultimately therefore, maintaining refugee status should be recognised as an equally important means of pursuing rights. It should not be dismissed on the assumption that membership to a state has any saliency independent of its capacity to protect refugees. In this context, the merits of both citizenship-based solutions and keeping a refugee identity can be recognised. The experience of the last sixty years have demonstrated that on its own, neither solution is particularly well-adapted to the Palestinian context, and therefore this is not a helpful dichotomy with which to resolve this situation. Instead, in addressing the plight of refugee populations in Lebanon, the tendency to dichotomise these positions must be resisted and a composite approach may be more appropriate.

Palestinian refugees in Lebanon are "amongst the most disadvantaged in any field, suffered from poor living and housing conditions, restrictions on mobility and high rates of unemployment." ${ }^{13}$ More than sixty years after the initial Palestinian exodus from Mandate Palestine, these refugees continue to face systematic discrimination and violent persecution. Ongoing marginalisation and the comprehensive failure of a final resolution to the Israeli-Palestinian conflict represents a "manifest in the inability to provide a solution for nearly four million Palestinian refugees, who... remain in exile." ${ }^{54}$ While Arzt, Allain and others promote citizenship as a basis for guaranteeing the provision of basic rights for these refugees, it is clear that resettlement in Lebanon and return to Israel are both unrealistic and ineffective solutions. Repatriation to a new Palestinian state also presents significant challenges and may further compromise the situation of Palestinians who are unable to take up the offer of citizenship. This analysis demonstrates that while citizenship may provide basic rights, entitlement and a sense of belonging for some refugee populations, it is not an option that holds much promise for Palestinians in Lebanon. Citizenship solutions are not necessarily well-adapted to all refugee situations; rather, their saliency lies in their capacity to secure basic conditions. In the case of Palestinian refugees in particular, maintaining refugee status and forgoing membership to any state is a form of political capital that allows access to international protection schemes and ensures the continuing relevance and visibility of the Palestinian plight. Although this tactic has also encountered difficulty, it is clear that a solution may require a composite approach that recognises the merits and limitations of both positions. For the four hundred thousand Palestinian refugees still living in Lebanon, "the refugee question remains the Holy Grail of Palestinian politics." 55

52 Khalil, "Palestinian Nationality and Citizenship", 29.

53 Jean Allain, International Law in the Middle East, 111.

54 Ibid, 101.

55 International Crisis Group, "Palestinian Refugees and the Politics of Peacemaking", 10. 